\title{
Pengaruh Lingkungan Kerja terhadap Produktivitas Pelayanan Pemerintah Kota Manado
}

\author{
GRACE JENNY SOPUTAN \\ Program Studi Manajemen, Fakultas Ekonomi, Universitas Negeri Manado \\ email: gracesoputan@gmail.com
}

\begin{abstract}
Manado City Government in carrying out their duties like providing excellent service to the public as a form of public service are maximized. This research aims determine whether the work environment has a positive effect on the service productivity of Manado City Government employees. Method research used is survey, data technique using questioner. The number of respondents 91 employees consisting Work unit exercising the licensing services. Data analysis using regression and correlation analysis. The results showed that there is a positive influence of Work Environment on productivity services. Research results proclaim that there is a positive effect of the Work Environment on Productivity Services.
\end{abstract}

Keywords: Work Environment, Service Productivity

\begin{abstract}
Abstrak. Pemerintah Kota Manado dalam menjalankan tugasnya ingin memberikan pelayanan prima kepada masyarakat sebagai wujud pelayanan publik yang maksimal. Produktivitas pelayanan akan maksimal jika lingkungan kerja kondusif dan menyenangkan. Tujuan penelitian ini untuk mengetahui apakah lingkungan kerja berpengaruh positif terhadap produktivitas pelayanan pegawai Pemerintah Kota Manado. Penelitian ini dilaksanakan pada pegawai BP2T sebanyak 91 responden. Metode yang digunakan adalah survey, dengan teknik pengumpulan data angket. Analisis data menggunakan analisis regresi dan korelasi. Hasil penelitan menunjukkan bahwa terdapat pengaruh positif Lingkungan Kerja terhadap Produktivitas Pelayanan.
\end{abstract}

Kata Kunci: Lingkungan kerja, Produktivitas Pelayanan.

\section{Pendahuluan}

Buruknya pelayanan publik bukan hal baru, fakta di lapangan masih menunjukkan hal tersebut. Belum ada motivasi untuk mengejar prestasi kerja yang maksimal dari para pegawai sehingga menyebabkan produktivitas kerja kurang meningkat. Hal lain yang menyebabkan produktivitas menurun adalah jiwa melayani belum merata pada semua pegawai. Tidak semua pegawai dapat memberikan pelayanan yang memuaskan kepada masyarakat.

Blecher dalam Wibowo (2010: 109) memberikan pengertian produktivitas dapat dikuantifikasi dengan membagi keluaran dan masukan. Menaikkan produktivitas dapat dilakukan dengan memperbaiki rasio produktivitas, dengan menghasilkan lebih banyak keluaran atau output yang lebih baik dengan tingkat masukan sumber daya tertentu.

Pelayanan publik berdasarkan surat Keputusan Menteri Negara Pendayagunaan Aparatur Negara Nomor 63/KEP/M.PAN/7/2003 tentang Pedoman Umum Penyelenggaraan Pelayanan Publik maka dilihat dari produk pelayanan, pelayanan publik dapat dikelompokkan menjadi 3 jenis, yaitu pertama, Kelompok Pelayanan Administratif yaitu pelayanan yang menghasilkan berbagai bentuk dokumen resmi yang dibutuhkan oleh publik, misalnya status kewarganegaraan, sertifikat kompetensi, kepemilikan atau penguasaan terhadap suatu barang dan sebagainya. Dokumen-dokumen ini antara lain Kartu Tanda Penduduk (KTP), Akte Pernikahan, Akte Kelahiran, Akte Kematian, Buku Pemilik Kendaraan Bermotor (STNK), Ijin Mendirikan Bangunan (IMB), Paspor, Sertifikat Kepemilikan/ Pengusaan Tanah dan sebagainya.

Kedua, Kelompok pelayanan barang yaitu pelayanan yang menghasilkan berbagai bentuk/ jenis yang digunakan oleh publik, misalnya jaringan telpon, penyediaan tenaga listrik, air bersih dan sebagainya. Ketiga, Kelompok Pelayanan Jasa yaitu pelayanan yang menghasilkanberbagai bentuk jasa yang dibutuhkan oleh publik, misalnya pendidikan, 
pemeliharaan kesehatan, penyelenggaraan transportasi, pos dan sebagainya. Selama ini pemerintah sebenarnya selalu mengumandangkan bahwa para pegawai pemerintah adalah merupakan abdi masyarakat. Sebagai abdi masyarakat, sudah jelas bahwa tugas utama dari para pegawai pemerintah adalah memberikan pelayanan yang terbaik kepada masyarakat. Sejak terjadinya krisis moneter dan krisis kepercayaan yang mengakibatkan perubahan dramatis pada tahun 1998, Indonesia telah memulai berbagai inisiatif yang dirancang untuk mempromosikan Good Governance, akuntabilitas dan partisipasi yang luas. Ini sebagai awal yang penting dalam menyebarluaskan gagasan yang mengarah pada perbaikan governance. Good Governance dipandang sebagai paradigma baru dan menjadi ciri yang perlu ada dalam sistem administrasi publik.

Dalam meningkatkan kualitas pelayanan publik Pemerintah Kota Manado melaksanakan upaya untuk memberikan yang terbaik bagi masyarakat, antara lain dalam pelayanan perizinan maka dibentuk unit pelayanan terpadu yaitu Badan Pelayanan Perijinan Terpadu (BP2T) yang diharapkan dapat lebih membantu masyarakat untuk mengurus administrasi perizinan seperti surat izin tempat usaha, izin mendirikan bangunan, izin usaha restoran dan lain-lain yang berjumlah 19 macam perizinan yang dilayani dalam satu atap. Diharapkan dengan adanya unit pelayanan terpadu akan memudahkan masyarakat dalam mengurus administrasi perizinan. Semua upaya yang dilakukan akan terwujud apabila didukung sumber daya manusia yang mampu dan bertanggung jawab untuk menjadi pelayan masyarakat.

Meskipun pemerintah ingin memberikan pelayanan yang prima kepada masyarakat, tetapi masih ada saja hambatan dalam implementasinya, hal ini disebabkan karena kinerja dari pelayan masyarakat yaitu pegawai negeri yang ada di lembaga penyedia layanan perizinan belum memberikan yang maksimal. Berdasarkan survey pendahuluan ditemukan bahwa pegawai dalam memproses perizinan membutuhkan fasilitas pendukung, tetapi yang tersedia tidak sebanding dengan berkas yang akan diproses, artinya tidak mencukupi sehingga harus menunggu. Selain itu kemampuan dan sumber daya manusia yang melaksanakan tugas bervariasi, belum seluruhnya dapat menyelesaikan pekerjaan dengan cepat. Fenomena ini dapat terlihat misalnya izin mendirikan bangunan, data sampai dengan tahun 2010 bangunan di kota Manado yang tidak mempunyai IMB berjumlah 47.201 buah. Sedangkan yang mempunyai I MB 30.685 buah. J ika semua rumah ber I MB maka retribusi yang diterima oleh pemerintah kota akan lebih banyak dan akan memberikan kontribusi pada Pendapatan Asli
Daerah (PAD). Kelemahan lain yang dilihat dalam produktivitas pelayanan bahwa petugas teknis khususnya pengurusan IMB sangat terbatas sehingga apabila untuk meninjau lokasi yang akan dibuat IMB tidak terjangkau secara cepat jika pemohonnya banyak. Fasilitas yang digunakan untuk peninjauan lokasi, kurang memadai karena hanya ada kendaraan beroda dua (2 buah). Kurangnya fasilitas menyebabkan proses pengurusan I MB akan memakan waktu lama dan pemohon harus mengikuti daftar antrian. Padahal dalam standar operasional prosedur untuk mengurus IMB membutuhkan waktu 10 hari. Kenyataannya pengurusannya lebih dari 10 hari.

Berdasarkan beberapa permasalahan yang ada dalam pelayanan publik maka peneliti ingin mengkaji faktor Lingkungan Kerja Terhadap Produktivitas Pelayanan.

Sebagai dasar teori dalam mengkaji kedua variabel tersebut maka penelitian ini diperkuat dengan teori tentang Lingkungan Kerja dan Produktivitas Pelayanan.

Lingkungan kerja terdiri dari lingkungan fisik berupa ruang kerja, fasilitas kerja, penerangan, udara, dan lingkungan sosial adalah iklim organisasi yaitu kondisi sosial berupa hubungan antara atasan dengan bawahan, hubungan antara sesama pegawai, dan suasana kerja. Lingkungan kerja yang kondusif sangat diperlukan untuk mewujudkan Produktivitas Pelayanan yang baik. Kondisi lingkungan yang sirkulasi udaranya baik, fasilitas kerja tersedia, penerangan ruangan memadai akan dapat membuat para pegawai bekerja dengan nyaman. Selain itu suasana kerja yang kondusif, hubungan atasan dan bawahan harmonis, hubungan harmonis antara para pegawai akan membuat para pegawai bekerja dengan tenang, dengan demikian akan menghasilkan pekerjaan yang efektif dan efisien. Dengan demikian diduga terdapat pengaruh positif antara lingkungan kerja dengan Produktivitas Pelayanan.

\section{Konsep Produktivitas Pelayanan}

Kopelman (1986: 3) mendefiniskan productivity is the relationship between physical output and one or more of the associated physical inputs used in the production process. Kopelman melihat produktivitas adalah keluaran dari suatu input. Produktivitas dipengaruhi oleh banyak faktor seperti the amount and technical sophistication of capital equipment, the quality and availability of raw materials, the scale of operations, the skills, motivation and attitude of employees, organizational work flow, and managerial competence. Selanjutnya Kopelman (1986: 4) mengaitkan produktivitas dengan efektifitas dan efisiensi. Sama halnya dengan Cascio (2010: 21), dia menyatakan 
bahwa produktivitas merupakan suatu pengukuran keluaran dihubungkan dengan masukan berupa tenaga kerja, modal, dan peralatan. Lebih lanjut dikatakan the more productive an industry, the better its competitive position because its unit cost are lower. When productivity increases, businesses can pay higher wages without boosting inflation. Selanjutnya The Japan Productivity Centre (JPC) and the European Productivity Agency (EPA) dalam Flora Han (2000: 132-133) mendefinisikan:

productivity as an attitude of mind that seeks to continually improve what already exists. Selanjutnya Singapore National Productivity Board (NPB) defines productivity as an attitude of mind that strives for and achieves the habit for improvements, as well as the systems and the set of practices that translate that attitude into action.

Ivancevich (2010: 3 4-35) memberikan definisi tentang produktivitas sebagai berikut:

\begin{abstract}
Outputs of goods and services per unit of input of resources used in a production process. Inputs, as applied in the measurement of productivity, are expressions of the physical or dollar amount of several elements used in producing a good or service, including labor, capital, materials, fuel and energy. "Productivity" is traditionally defined as the ratio between output (e.g. the quantity of products or services produced) and input (e.g. the time needed for production) (Sink, 1983). Productivity is regarded as a key success factor of organisations. Productivity measurement can potentially be a useful tool for monitoring productivity development and for guiding improvement efforts. However, finding useful productivity measures in the public sector has proved problematic. (2011:289). Broman points out the inherent similarities in many definitions of productivity; the basic content seems to be the same. Ghobadian and Husband dalam dStefan Tangen (2005: 34-46) however, suggest that, within the similar definitions, there are three broad categorisations: (1) the technological concept: the relationship between ratios of output to the inputs used in its production. (2) The engineering concept: the relationship between the actual and the potential output of a process. (3) The economist concept: the efficiency of resource allocation
\end{abstract}

Menurut Kamus Besar Bahasa Indonesia (2005: 15) bahwa pelayanan adalah perihal atau cara melayani. Pelayanan dapat diartikan sebagai tindakan atau perbuatan seseorang atau organisasi untuk memberikan kepuasan kepada pelanggan atau nasabah. Selanjutnya Fitzsimons (2011: 89) mengutip pendapat Gronroos,

services is an activity of series of activities of more or less intangible nature that normally, but not necessarily, take place in interactions between customer and service employees and/ orphysical resources or good and/or systems of the service provider, which are provided as solution to customer problems.

Sedarmayanti (2011: 26) menyetir pendapat Arouf menyatakan bahwa produktivitas memiliki dua dimensi, yakni efektifitas dan efisiensi pengunaan sumber masukan. Dimensi efektifitas berkaitan dengan pencapaian kerja yang maksimal, artinya pencapaian target yang berkaitan dengan kualitas, kuantitas dan waktu dimensi efisiensi merujuk kepada upaya membandingkan masukan dengan realisasi penggunaannya atau bagaimana pekerjaan dilaksanakan. Menurut Jaaskelainen (2011: 289-302):

The concept of "service productivity" has been introduced in order to highlight the specific characteristics of services in the context of productivity considerations. The service literature extends the traditional examination of productivity by stressing factors such as the quality of service, utilisation of service providing capacity and the role of customers in service provision. Several service productivity models can be found in the literature For example, Gro" nroos and Ojasalo dalam Jaaskelainen (2011:289-302) define service productivity as a function of internal efficiency (i.e. the service provider's pro-ductivity), external efficiency (i.e. the productivityfrom the customer's perspective: perceived value per sacrifice) and capacity efficiency (i.e. the utilisation of service capacity).

Selanjutnya, dikatakan Jaaskelainen mensetir pendapat dari Boyne, dan Midwinter, dalam produktivitas pelayanan terdapat model 3 E yaitu economy, efficiency dan effectiveness dan IOO yaitu input, outputs dan outcomes. Beberapa model produktivitas pelayanan yang dikemukakan oleh Grönroos and Ojasalo, Parasuraman, Jääskeläinen and Lönnqvist, dalam Antti Lönnqvist, Harri Laihonen (2010: 3), menyimpulkan ada tiga faktor produktivtas pelayanan tersebut yaitu quality of service, utilization of service capacity and the role of customers in service production. Penjelasan selanjutnya dikatakan dalam pelayanan publik, produktivitas berhubungan erat dengan cost-efficiency and quality of services. The productivity of public services can be improved either by producing more outputs of better quality at the same cost or by producing the same number of outputs of the same quality at less cost.

Filipo (2011: 289-302) dalam Jaaskelainen identifies two extremes on the goods/services continuum: the "pure product" presents the least intangible content, while the "pure service" has intangible content as its maximum. Edvardson et al menjelaskan Service dominant mindset adalah sebagai berikut: (1) Service(s); (2) Intangible; (3) Operant resources; (4) Symmetric information; (5) Conversation; (6) Value proposition; (7) Relational; (8) Financial feedback. Pendapat di atas memberikan penjelasan bahwa salah satu faktor produktivitas pelayanan adalah kualtias pelayanan. Beberapa studi mengidentifikasi ketika mengevaluasi service quality, Gro"nroos classified these dimensions into two categories: (1) "func- 
tional quality" (the process of service delivery); and (2) "technical quality" (what consumers actually receive from the service.

Berdasarkan beberapa pendapat tentang produktivitas dan pelayanan maka dapat disintesiskan bahwa produktivitas pelayanan adalah sikap pikiran yang mencari cara dalam meningkatkan apa yang sudah ada secara berkelanjutan dengan memperhatikan efektifitas dan efisiensi penggunaan sumber daya yang dimiliki organisasi untuk membantu dan memuaskan orang lain dengan indikator efektifitas, efisiensi, kualitas pelayanan, dan utilitas.

\section{Konsep Lingkungan Kerja}

Lingkungan kerja dapat dilihat dari lingkungan fisik dan lingkungan sosial. Luthans (2006: 2) melihat salah satu praktek dasar Gallup mencakup pengukuran dan pengembangan keterlibatan karyawan yang mengacu pada terciptanya tempat kerja yang nyaman, untuk memberi ukuran dimana individu ditempatkan dan dikelola secara benar, menciptakan ruang kerja yang nyaman. Selanjutnya dijelaskan studi yang berhubungan dengan tempat kerja mengilustrasikan validitas ukuran yang tepat dan manajemen talenta untuk memprediksi rating performa kerja supervisor, volume penjualan, catatan produksi, dan ketidakhadiran. Menurut Model Gallup bahwa salah satu faktor yang mempengaruhi kinerja adalah tempat kerja yang nyaman. Salah satu faktor yang mempengaruhi kinerja adalah Job Content yang salah satu dimensinya adalah physical environment (lingkungan fisik). Steers (1985: 120) mengatakan bahwa variasi lingkungan dalam karya dan efektivitas tidak akan lengkap tanpa mempertimbangkan sifat lingkungan dalam. Yang dimaksudkan lingkungan dalam adalah lingkungan kerja. Selanjutnya dikatakan lingkungan yang dirasakan sering disebut iklim organisasi. Watkin \& Hubbard dalam Prianto (2006:32) menjelaskan bahwa suasana kerja adalah ukuran yang dinyatakan dari persepsi pekerja tentang berbagai aspek dari lingkungan kerjanya yang secara langsung memiliki pengaruh terhadap kelancaran pekerja didalam menyelesaikan pekerjaannya.

Ada beberapa ahli yang mencoba untuk menentukan faktor-faktor yang merupakan bagian dari variabel lingkungan kerja. Berdasarkan pendapat para ahli dan para peneliti, maka dapat diketemukan beberapa faktor antara lain lingkungan kerja fisik dan lingkungan kerja non fisik. Lingkungan kerja diartikan tempat kerja yang nyaman: (Luthan, 2006:2) Lingkungan kerja disebut juga iklim organisasi, semangat kerja sama diantara pegawai (Boshoff \& Allen, Steers); kualitas hubungan atasan dan bawahan dan hubungan antar sesama pegawai (Suliman \& Iles). Newstorm (1985: 189) mengemukakan pengertian iklim organisasi sebagai The human environment within an organization's employees do their work. Pernyataan tersebut mengandung arti bahwa iklim organisasi itu adalah yang menyangkut semua lingkungan yang ada atau yang dihadapi oleh manusia di dalam suatu organisasi tempat mereka melaksanakan pekerjaannya. Selanjutnya, Newstorm (1985: 189) menyebutkan bahwa iklim organisasi dapat berada di salah satu tempat pada kontinum yang bergerak dari yang menyenangkan ke yang netral sampai dengan yang tidak menyenangkan. Majikan dan karyawan menginginkan iklim yang lebih menyenangkan karena maslahatnya, seperti kinerja yang lebih baik dan kepuasan kerja. Unsur-unsur yang mengkontribusi terciptanya iklim yang menyenangkan adalah (1) kualitas kepemimpinan; (2) kadar kepercayaan; (3) komunikasi, ke atas dan ke bawah; (4) perasaan melakukan pekerjaan yang bermanfaat; (5) tanggung jawab; (6) imbalan yang adil; (7) tekanan pekerjaan yang nalar; (8) kesempatan; (9) pengendalian, struktur, dan birokrasi yang nalar; dan (10) keterlibatan pegawai, partisipasi.

Saat ini, para peneliti setuju bahwa faktorfaktor dan kondisi-kondisi utama yang mana untuk konstitusi pekerjaan yang baik mengklaim terdapat tiga kategori yang menarik dalam lingkungan kerja yaitu: (1) content and character of the work; (2) deals with the organization of the work and employee's possibilities for self-control, and; (3) concerns the social relations in the work, especially social support (2003: 149). Ketiga faktor tersebut dapat ditambahkan dengan kesehatan fisik. Edvardson and Gustavsson dalam Mikhadasi (1999: 47-55) menyimpulkan atas penelitian mereka tentang kualitas dalam lingkungan kerja yang mereka namakan the good Work memberikan kesempatan kepada para individu:

(1) Exercise influence and control over one's own work situation; (2) Develop security and meaning;

(3) Develop social relations at and through the job;

(4) Keep a social distance to the job; (5) Maintain good health and avoid negative stress; (6) Work in safe physical surroundings.

Mikdashi menambahkan kreativitas merupakan aspek dari lingkungan kerja.

To address this issue, the present study examines the construct validity of the KEYS instrument, Amabile et al. dalam Mikhadashi (1999: 47-55), in order to gain further insights into the factors stimulating or hindering creativity in Lebanon and to create an environment infrastructure that encourages and reinforces creativity indeveloping countries. Dalam penelitian Mikhadashi menggunakan KEYS instrument yaitu six factors underlying the KEYS instrument sebagai berikut: (1) Faktor I : creativity 
and challenging work; (2) Factor II: workload pressure; (3) Factor III: superviso ry encouragement; (4) Factor IV: organizational impediments; (5) Faktor V: workgroup support; and; (6) Factor VI: sufficient resources.

Lingkungan fisik memengaruhi seseorang dalam bekerja, lingkungan yang memengaruhi antara lain kebisingan, pencahayaan, dan suasana kerja, termasuk suhu udara dan kelembaban udara, adalah faktor yang penting didalam lingkungan kerja/kondisi kerja. Banyak penelitian yang telah menunjukkan bukti yang mengindikasikan bahwa kondisi kerja dapat mempengaruhi kenyamanan pekerja, kesehatannya, dan kinerjanya (David, 1984: 499). Menurut Steers (1985: 125) iklim organisasi dapat dipandang sebagai kepribadian organisasi seperti yang dilihat oleh para anggotanya. Pengertian ini mengandung makna bahwa yang dimaksud dengan iklim bukanlah iklim yang sebenarnya, tetapi menyangkut perasaan yaitu apa yang dirasa oleh anggota organisasi yang bersangkutan. Setiap organisasi mempunyai kepribadian yang berbeda-beda. Kepribadian ini tergambar dalam unsur sosial dan budaya tempat berlangsungnya kegiatan dari suatu organisasi. Selanjutnya Payne dan Hugh dalam Steers mengatakan bahwa iklim organisasi terutama adalah sikap, nilai norma dan perasaan yang lazim dimiliki para pekerja sehubungan dengan organisasi mereka. Litwin dan Stringer dalam Koontz, et al, (1984: 63) mengatakan iklim organisasi sebagai pengaruh subjektif dari sistem formal, gaya informal manajer dan faktor-faktor lingkungan lainnya dalam sikap, keyakinan, nilai, dan motivasi kerja manusia di sebuah organisasi. Untuk mengukur iklim organisasi melalui persepsi dan perasaan anggota-anggota terhadap sembilan kategori (dimensi) iklim, yaitu: (1) structure (struktur), yaitu struktur yang kaku dengan pengaturan, tata tertib, dan prosedur; (2) responsibility (tanggung jawab) yaitu perasaan menjadi atasan terhadap diri sendiri; (3) reward (imbalan), berupa pemekaran terhadap imbalan positif dan hukuman; (4) risk (resiko) berupa pemekaran terhadap pengambilan resiko dan tantangan; (5) warmth (kehangatan) yaitu suasana kelompok yang bersahabat; (6) support (dukungan) yaitu dukungan timbal balik manajer dan rekan yang membantu; (7) standards (ukuran) berupa persepsi atas tujuan yang implisit dan eksplisit serta standar prestasi kerja baik, dan tantangan dalam tujuan; (8) conflict (pertentangan) yaitu pengutamaan pada upaya mendengarkan pendapat yang berbeda dan mengungkapkan masalah secara terbuka; (9) identity (pengidentifikasian) berupa perasaan bahwa seseorang merupakan bagian dari organisasi dan merupakan anggota tim yang berharga (Koontz, 1984: 62). Sedarmayanti
(2011:26) memberikan klasifikasi lingkungan kerja meliputi: (1) Lingkungan fisik yang terbagi atas lingkungan yang langsung berhubungan dengan pegawai yaitu seperti pusat kerja, kursi, meja dan sebagainya; (2) Lingkungan perantara atau lingkungan umum seperti rumah, kantor, pabrik, sekolah, kota, system jalan raya, dan sebagainya. Selanjutnya dikatakan faktor yang dapat memengaruhi terbentuknya suatu lingkungan kerja yang dikaitkan dengan kemampuan manusia/pegawai diantaranya adalah: (1) penerangan/cahaya di tempat kerja; (2) temperature/suhu udara; (3) Kelembaban; (4) Sirkulasi Udara; (5) Kebisingan; (6) Getaran mekanis; (7) Bau tidak sedap; (8) Tata warna; (9) Dekorasi; (10) Musik; (11) Keamanan.

Berdasarkan uraian diatas tentang lingkungan kerja maka dapat disintesiskan bahwa lingkungan kerja adalah tempat atau ruangan dan fasilitas dimana seseorang mengadakan aktifitas serta suasana interaksi yang nyaman dan menyenangkan diantara orang-orang yang ada dalam organisasi yang ditunjukkan dalam dua dimensi yaitu lingkungan fisik dengan indikator ruang kerja; fasilitas kerja; penerangan; sirkulasi udara; dan dimensi lingkungan sosial dengan indikator: iklim organisasi, semangat kerja sama diantara pegawai; kualitas hubungan antara atasan dan bawahan; serta hubungan antara sesama pegawai.

\section{Metode Penelitian}

Metode penelitian yang digunakan adalah metode survey untuk mendapatkan data nyata atas hal-hal yang dialami dan dilaksanakan responden untuk membahas lingkungan kerja terhadap produktivitas pelayanan. Populasi sasaran adalah unit kerja (SKPD) yang melaksanakan pelayanan administrasi perijinan terpadu yaitu BP2T, Dinas Tata Kota, Dinas Perindustrian dan Perdagangan, Dinas Pekerjaan Umum, dan Bagian Perekonomian.Sedangkan populasi terjangkau adalah seluruh pegawai yang bergolongan III dan IV. Ukuran sampel $n$ ditentukan dengan menentukan $\alpha=0,05 \quad \beta=0,95 r=0,25$ maka diperoleh ukuran sampel $\mathrm{n}=168$ responden. Campbell (1997: 89-92)

J adi ukuran sampel n perkiraan adalah 168 . Jumlah anggota populasi sebanyak 194 orang Untuk mendapatkan ukuran sampel yang sebenarnya digunakan rumus sebagai berikut:

$$
\begin{aligned}
& n=\frac{n_{0}}{1+\frac{n_{0}}{N}}(1991: 125) \\
& \mathrm{n}=\frac{168}{1+168 / 194}=90,032=91 .
\end{aligned}
$$

Berdasarkan perhitungan tersebut didapat 
$\mathrm{n}=91$. Jumlah responden sebanyak 91 orang pegawai. Teknik penarikan sampel menggunakan proportional random sampling. Ukuran sampel $n$ diperoleh $i=\frac{N i}{N \times n}$

\begin{tabular}{lllc}
\hline $\begin{array}{l}\text { No. Nama } \\
\text { Lembaga }\end{array}$ & $\begin{array}{l}\text { Jumlah } \\
\text { Populasi }\end{array}$ & $\begin{array}{c}\text { Jumlah } \\
\text { (n) }\end{array}$ \\
\hline 1 & BP2T & 27 & $27 / 194 \times 91=13$ \\
2 & $\begin{array}{l}\text { Dinas Tata Kota } \\
3\end{array}$ & 53 & $53 / 194 \times 91=25$ \\
4 & $\begin{array}{l}\text { Dinas Perindag } \\
\text { Bagian }\end{array}$ & 35 & $35 / 194 \times 91=16$ \\
Perekonomian & 18 & $18 / 194 \times 91=8$ \\
5 & Dinas PU & 61 & $61 / 194 \times 91=29$ \\
\hline & Total & $\mathbf{1 9 4}$ & $\mathbf{9 1}$ \\
\hline
\end{tabular}

Teknik pengumpulan data dilakukan dengan menggunakan instrumen berupa angket untuk menilai produktivitas pelayanan, dan lingkungan kerja. Instrumen penelitian menggunakan skala Likert dengan lima pilihan jawaban yang terdiri dari pernyataan positif dan negatif. Sebelum instrument digunakan sebagai alat pengumpulan data penelitian, terlebih dahulu diuji-cobakan validitasnya (keabsahan) dan reliabilitas (kehandalan). Analisis data menggunakan analisis regresi linier sederhana dan korelasi.

\section{Pengaruh Lingkungan Kerja terhadap Produktivitas Pelayanan}

Instrumen produktivitas pelayanan yang digunakan dalam penelitian ini terdiri dari 13 butir pertanyaan yang valid. Rentang skor teoretik yaitu 13 sampai dengan 65. Sesuai dengan hasil data penelitian, diperoleh data terendah 31 dan data tertinggi 65. Dengan demikian maka rentang skor adalah 34. Data penelitian selanjutnya diperoleh nilai rata-rata sebesar 43, modus 42 dan median 42, sedangkan standar deviasi atau simpangan baku sebesar 7,4858 dan varians 56,037. Sesuai hasil perhitungan jumlah kelas interval sebanyak 6 kelas dan panjang kelas interval adalah 5 .
Adapun sebaran data variabel Produktivitas Pelayanan ditampilkan dalam bentuk Tabel distribusi frekuensi sebagaimana pada Tabel 1.

Instrumen lingkungan kerja yang digunakan dalam penelitian ini terdiri dari 17 butir pertanyaan yang valid.Rentang skor teoretik yaitu 17 sampai dengan 85. Sesuai dengan hasil data penelitian, diperoleh data terendah 40 dan data tertinggi 84. Dengan demikian maka rentang skor adalah 44. Data penelitian selanjutnya diperoleh nilai ratarata sebesar 64,64 modus 64 dan median 65 , sedangkan standar deviasi atau simpangan baku sebesar 8,58. Dengan menggunakan aturan Sturgess, diperoleh kelas interval 7 dan panjang kelas interval 6 sehingga dapat dibuat distribusi frekuensi skor Lingkungan Kerja seperti Tabel 2.

Berdasarkan hasil perhitungan regresi sederhana pengaruh Lingkungan kerja terhadap produktivitas pelayanan diperoleh konstanta (a) sebesar -3,092 dan koefisien regresi (b) 0,71. Dari nilai konstanta dan koefisen regresi tersebut, maka dapat dituliskan persamaan regresi pengaruh lingkungan kerja terhadap produktivitas pelayanan, $v=-3,092+0,714 X_{3}$. Hasil perhitungan uji signifikansi dan linearitas atas persamaan regresi tersebut disajikan pada tabel analisis varians (ANAVA) sebagaimana tampak pada Tabel 3.

Dari Tabel 3 diketahui nilai $F_{\text {hitung }}$ sebesar 181.779 , sedangkan $\mathrm{F}_{\text {tabel }}$ pada taraf signifikansi $(\alpha)$ 0,05 adalah 3,948 . Nilai $F_{\text {hitung }}>F_{\text {tabel, }}$ sehingga dapat disimpulkan bahwa persamaan regresi produktivitas pelayanan atas lingkungan kerja adalah signifikan. Sementara untuk uji linearitas diperoleh nilai $F_{\text {hitung }}=1.063$ sedangkan nilai $F_{\text {tabel }}$ pada taraf signifikansi $(\alpha)=0,05$ dengan $\mathrm{dk}$ pembilang $32 \mathrm{dk}$ penyebut 57 sebesar 1.646 . Hasil tersebut menunjukkan bahwa nilai $\mathrm{F}_{\text {hitung }}<\mathrm{F}_{\text {tabel' }}$ sehingga dapat disimpulkan bahwa persamaan regresi variabel produktivitas pelayanan atas lingkungan kerja berbentuk linier.

Koefisien Korelasi sebesar 0,819 sedangkan koefisien determinasi sebesar 0,671. Uji signifikansi korelasi pada taraf nyata 0,05 t hitung $=13,483$

Tabel 1

Distribusi Frekuensi Skor Produktivitas Pelayanan (Variabel Y)

\begin{tabular}{|lllll|}
\hline No. & Interval Kelas & Mutlak & $\begin{array}{l}\text { Frekuensi } \\
\text { Relatif }\end{array}$ & Kumulatif \\
\hline 1 & $31-36$ & 21 & 19.63 & 19.63 \\
2 & $37-42$ & 41 & 38.32 & 57.95 \\
3 & $43-48$ & 27 & 25.23 & 83.18 \\
4 & $49-54$ & 11 & 10.28 & 93.46 \\
5 & $55-60$ & 4 & 3.74 & 97.20 \\
6 & $61-66$ & 3 & 2.80 & 100.00 \\
\hline \multicolumn{2}{l}{ Jumlah } & $\mathbf{9 1}$ & $\mathbf{1 0 0 . 0 0}$ & \\
\hline
\end{tabular}


sedangkan t tabel $=1,987$. Dengan demikian koefisien korelasi $X$ terhadap $Y$ adalah signifikan.

Hasil pengujian hipotesis memberikan penegasan secara empiris bahwa lingkungan kerja mempunyai pengaruh terhadap produktivitas pelayanan. Dengan demikian menurunnya produktivitas pelayanan sudah dapat dipastikan akan secara signifikan berimplikasi terhadap menurunnya produktivitas pelayanan. Produktivitas pelayanan yang tercermin pada efektifitas dalam memberikan pelayanan dan juga efisiensi dalam memberikan pelayanan kalau tidak ditunjang oleh lingkungan kerja yang nyaman dan menyenangkan maka produktivitas pelayanan tidak akan meningkat. Dalam hal ini para pegawai dapat bekerja dengan maksimal kalau di tunjang dengan fasilitas kerja dan iklim organisasi yang memadai. Sebab lingkungan kerja yang dimaksud bukan hanya lingkungan fisik tetapi juga lingkungan sosial. Lingkungan sosial yang dimaksud adalah iklim kerja atau suasana kerja yang menyenangkan, semangat kerja, terjalin kerjasama antara pimpinan dengan pegawai dan juga interaksi sesama pegawai.

Lingkungan fisik memengaruhi seseorang dalam bekerja, lingkungan yang memengaruhi antara lain kebisingan, pencahayaan, dan suasana kerja, termasuk suhu udara dan kelembaban udara, adalah faktor yang penting didalam lingkungan kerja/ kondisi kerja. Banyak penelitian yang telah menunjukkan bukti yang mengindikasikan bahwa kondisi kerja dapat memengaruhi kenyamanan pekerja, kesehatannya, dan kinerjanya (David, 1984: 499).

Lingkungan kerja, tempat dimana sehariharinya para karyawan melakukan aktifitas kerja memiliki pengaruh yang sangat besar terhadap performa kerja mereka. Pfefer dalam Prianto (2006: 160) menyatakan bahwa lingkungan tempat bekerja adalah sangat besar pengaruhnya terhadap produktifitas kerja. Edvarsson Bo dan BengtOve Gustavsson dalam penelitian mereka mengatakan bahwa kualitas lingkungan kerja merupakan prasyarat untuk sukses dalam pengembangan pelayanan yang baru. Artinya terdapat lima persyaratan yang harus dipenuhi dalam organisasi berfokus pelayanan. Sementara penelitian dari Watkin \& Hubbart dalam Prianto (2006: 32) menunjukkan bahwa dalam organisasi bisnis, semakin besar ikllim kerja yang positif, maka akan semakin besar pula pendapatan bersih yang akan didapatkan. Edvardson and Gustavsson (2003: 149) menyimpulkan atas penelitian mereka tentang kualitas dalam lingkungan kerja yang mereka namakan the good Work memberikan kesempatan kepada para individu: (1) Exercise influence and

Tabel 2

Distribusi Frekuensi Skor Lingkungan Kerja (Variabel X)

\begin{tabular}{|lllll|}
\hline No. & Interval Kelas & Mutlak & $\begin{array}{l}\text { Frekuensi } \\
\text { Relatif (\%) }\end{array}$ & Kumulatif \\
\hline 1. & $40-46$ & 2 & 2,20 & 2,20 \\
2. & $47-53$ & 8 & 8,79 & 10,99 \\
3. & $54-60$ & 16 & 17,58 & 28,57 \\
4. & $61-67$ & 30 & 32,97 & 61,54 \\
5. & $68-74$ & 25 & 27,47 & 89,01 \\
6. & $75-81$ & 9 & 9,89 & 98,90 \\
7. & $82-88$ & 1 & 1,10 & 100 \\
\hline \multicolumn{2}{l}{ Jumlah } & & & \\
\hline
\end{tabular}

Tabel 3

Analisis Varians untuk Signifikansi dan Linearitas Regresi Lingkungan Kerja terhadap Produktivitas Pelayanan v=-3,092 + 0,714X

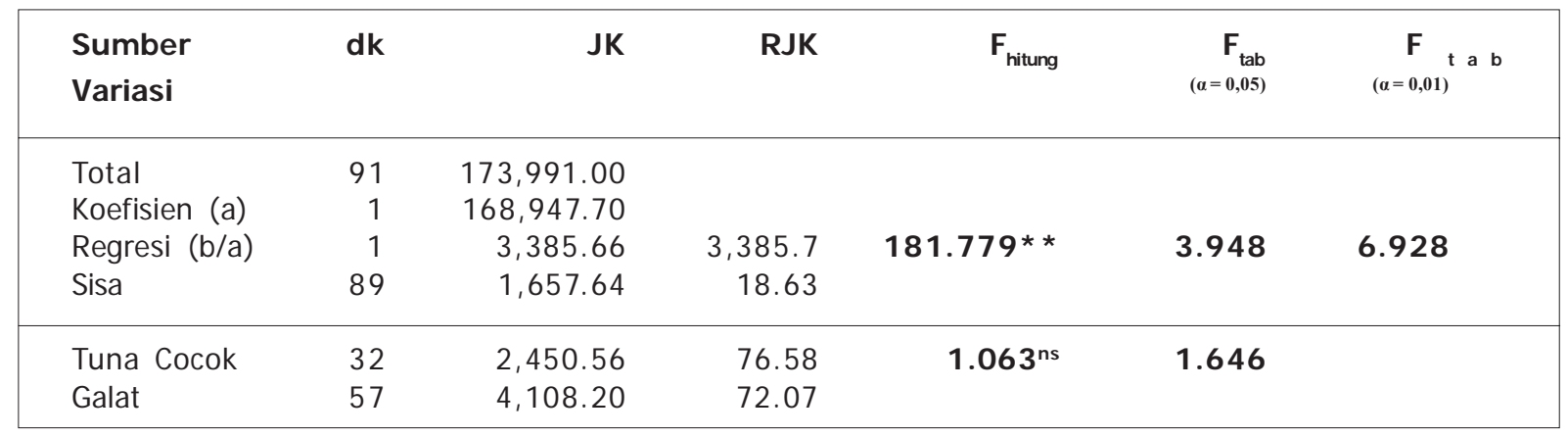


control over one's own work situation; (2) Develop security and meaning; (3) Develop social relations at and through the job; (4) Keep a social distance to the job; (5) Maintain good health and avoid negative stress; (6) Work in safe physical surrounding. Sedarmayanti (2011:28) mengatakan faktor yang dapat memengaruhi terbentuknya suatu lingkungan kerja yang dikaitkan dengan kemampuan manusia/pegawai diantaranya adalah (1) penerangan/cahaya di tempat kerja; (2) temperature/suhu udara; (3) Kelembaban; (4) Sirkulasi Udara; (5) Kebisingan; (6) Getaran mekanis; (7) Bau tidak sedap; (8) Tata warna; (9) Dekorasi; (10) Musik; (11) Keamanan.

Dengan demikian temuan ini semakin mempertegas hasil penelitian sebelumnya yang menunjukkan bahwa lingkungan kerja merupakan salah satu faktor yang berpengaruh secara signifikan terhadap produktivitas pelayanan.

Lingkungan kerja yang ada di Pemerintah Kota Manado khususnya dalam bidang pelayanan perijinan belum begitu memadai karena jika pelayanan perijinan dikatakan terpadu seyogyanya berada dalam satu atap dalam pengertian kantornya tidak terpisah-pisah sehingga dapat dinamakan juga pelayanan satu atap, karena jiwa dari pelayanan perijinan ini adalah pelayanan satu atap sehingga produktivitas pelayanan akan meningkat. Dengan demikian pemohon atau masyarakat yang ingin mendapatkan pelayanan dapat dengan cepat menerima pelayanan.

\section{Simpulan dan Saran}

Hasil penelitian menunjukkan bahwa terdapat pengaruh positif Lingkungan Kerja terhadap Produktivitas Pelayanan. Hal ini menunjukkan bahwa dengan adanya lingkungan kerja baik fisik maupun lingkungan sosial yang nyaman dan menyenangkan dapat meningkatkan produktivitas pelayanan di Pemerintah Kota Manado khususnya dalam pelayanan perijinan. Perbaikan lingkungan kerja dapat ditempuh melalui perluasan ruangan kerja dari setiap unit pelayanan perijinan yang ada di Pemerintah Kota Manado dan juga hubungan antara pimpinan dan para pegawai serta hubungan antar sesama pegawai.

\section{Daftar Pustaka}

Edvardson, B. and Bengtove, B. (2003). Service Quality, J urnal Managing Service quality.

Campbell, (1987). Statistical Tables for the Design of Clinical Trials, Blackwell Scientific Publication.

Cascio, (2010). Managing Human Resouces, Productivity, Quality of work life, Profits, McGraw-Hill Irwin.
Cochran, (1991). Teknik Penarikan Sampel, Universitas Indonesia.

David, A. (1994). Organizational Psychology, PrenticeHall, Engelwood Cliffs.

dStefan, Tangen, (2005). International Journal of Productivityand Performance Management. Vol. 54 No. 1, pp. 34-46 Emerald Group Publishing Limited.

Fitzimons J. A dan Mona J. Fitzimons, (2011). Jurnal Service Management, Operations, Strategy, Information Technologi.

Flora, H dan Leong, L. (2010) Productivity and Service Quality, Singapore

Gibson, J., L, Ivancevich J ohn, Donnelly James H,J r, Konopaske, R, Organizations, Behavior, Structure, Processes, McGraw Hill, Copyright 2011.

Ivancevich, (2010). Human Resource Management, Singapore.

Jaaskelainen, A, (2011) Public service productivity, International J ournal of Public Sector Management Vol. 24 No. 4, 2011, pp. 289-302)

Koontz, \& Donnel (1984) Management, a system and Contingency Analysis of Managerial Functions.

Kopelman R. E, (2010) Managing Productivity in Organizations, Singapore.

Lönnqvist, A. dan H. Laihonen, (2010) Jurnal Welfare Service.

Luthans, (2006) Organizational Behavior, Terjemahan, edisi sepuluh, Yogyakarta, Andi.

Mikdashi, T, (1999). Participation \& Empowerment: An International J ournal, Vol. 7 No. 3, pp. 47-55

Newstrom, Davis, (2002). Organizational Behavior, McGraw-Hill I rwin

Newstrom, D. (2011). Organizational Behavior, Human Behavior at Work, McGraw-Hill.

Prianto, A., (2006). Menakar Kualiltas Pelayanan Publik, Andi

Riadh, Ladhari, (2009). Service quality, emotional satisfaction, and behavioural intentions Journal Managing Service Quality Vol. 19 No. 3, pp.308-331

Robbins, S. P., (2011). Timothy A. Jugde, Organizational Behavior, Pearson.

Sedarmayanti, (2011). Tata Kerja dan Produktivitas Pelayanan, Bandung, Mandar Maju,

Steers, R, (1985). Efektivitas Organisasi, Erlangga

Voon, M.L., M.C. Lo, K.S. Ngui, N.B., Ayob, (2011). International J ournal of Business, Management and Social Sciences, Vol. 2, No. 1, pp. 24-32.

Wibowo, (2010). Manajemen Kinerja, Edisi kedua, Rajawali Pers. 